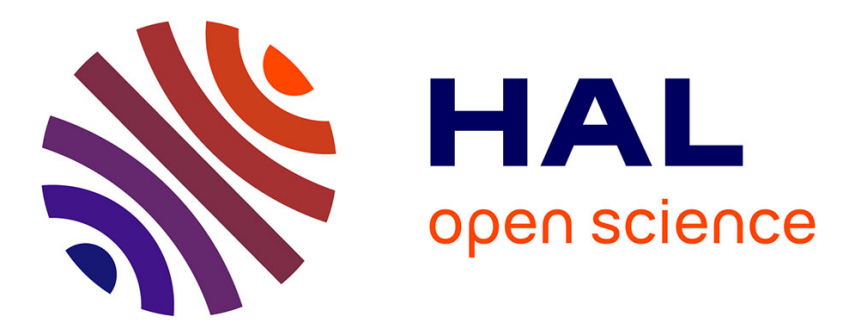

\title{
Going interdisciplinary in French and US universities: organizational change and university policies
}

\author{
Séverine Louvel
}

\section{To cite this version:}

Séverine Louvel. Going interdisciplinary in French and US universities: organizational change and university policies. Popp-Berman, Elizabeth; Paradeise, Catherine. The University Under Pressure, 46, Emerald Group Publishing, pp.329-359, 2015, Research in the Sociology of Organizations, 978-178560-831-5. halshs-01354901

\section{HAL Id: halshs-01354901 https://shs.hal.science/halshs-01354901}

Submitted on 7 Dec 2018

HAL is a multi-disciplinary open access archive for the deposit and dissemination of scientific research documents, whether they are published or not. The documents may come from teaching and research institutions in France or abroad, or from public or private research centers.
L'archive ouverte pluridisciplinaire HAL, est destinée au dépôt et à la diffusion de documents scientifiques de niveau recherche, publiés ou non, émanant des établissements d'enseignement et de recherche français ou étrangers, des laboratoires publics ou privés. 


\title{
Going interdisciplinary in French and US universities: organizational change and university policies
}

\author{
Séverine Louvel
}

\section{To cite this article}

Louvel, S. (2016) Going Interdisciplinary in French and US Universities: Organizational Change and University Policies, in Elizabeth Popp Berman, Catherine Paradeise (ed.) The University Under Pressure (Research in the Sociology of Organizations, Volume 46) Emerald Group Publishing Limited., pp.329 - 359.

\section{Summary}

This chapter analyses French and US universities' organizational responses to the more or less explicit pressures they face to go interdisciplinary. Defining universities as pluralistic organizations, I show that the implementation of interdisciplinary research does not result in well-integrated institutional strategies, but rather combines initiatives from the scientific community and from university leaders. Based on case studies conducted on the development of interdisciplinary nanomedicine in five leading French and US research universities, I identify three settings where the implementation of interdisciplinarity involves shifts in organizational structure - in principal investigator-based research teams and scientific networks, in departmental boundaries, and in institutional structures -, and question issues of governance, leadership and resource allocation arising from those shifts. We see similarities between the two countries in terms of how initiatives by 'entrepreneurial academics' - searching for funds for interdisciplinary research - and by the university leadership - also searching for funds, and redefining institutional projects around interdisciplinarity - complement each other. We also identify one major difference - with French pro-interdisciplinary university policies being strongly influenced by a political impetus from the French ministry of higher education and research.

\section{Keywords}

Interdisciplinarity, organizational change, university policy, nanomedicine, French and US universities

\section{Short bio}

Séverine Louvel is associate professor in the sociology of science at Sciences Po Grenoble (PACTE). She is the director of the master's program 'Technology, Science and Decisions' (Sciences Po Grenoble and Grenoble Institute of Technology), and a researcher at the PACTE research lab (CNRS and 
University of Grenoble). Her most recent research explores the organizational and professional dimensions of the development of interdisciplinary nanomedicine in French and US universities. 


\section{Introduction}

Interdisciplinarity finds continuing support, in both Europe and in the US, among policy makers (MESR, 2013, p.10) and university leaders (EUA, 2015, p.97; AAU, 2005), as well as from funding agencies (Hackett, 2000; Zerhouni, 2003; Global Research Council, 2013). ${ }^{1}$ Its promoters present it as being essential to advancing fundamental knowledge, for the social relevance of research, for business innovation and for technology transfer, and for students' employability. The development of interdisciplinary research and post-graduate education has resulted in a growing body of literature analyzing interdisciplinary practices as well as prointerdisciplinary university policies, questioning their relevance and examining the reasons behind their success or failure. Many studies are dedicated to US universities and analyze either the management and outcomes of the large interdisciplinary research centers funded mostly by federal funding agencies (Boardman \& Ponomariov, 2014; Boardman \& Corley, 2008; Ponomariov \& Boardman, 2010; Sabharwal \& Hu, 2013; Youtie, Libaers, \& Bozeman, 2006), or pro-interdisciplinary university policies (Brint, 2005; Holley, 2009; Hollingsworth \& Hollingsworth, 2000; Sá, 2008a). ${ }^{2}$ These studies show that, in the US context, interdisciplinary research initiatives are distributed among research teams, departments, research centers and universities - and often depend principally on the ability of faculty and university leaders to seize and sustain funding opportunities for interdisciplinary research, rather than being integrated into coherent institutional strategies. ${ }^{3}$ However, to what extent these findings are USspecific - notably because of the organization of research funding - or are relevant for non-US (for instance, French) universities is not clear. We assume the organizational changes

\footnotetext{
${ }^{1}$ Faculty opinion on interdisciplinarity seems to be more nuanced, however. A survey indicates that $70 \%$ of college and university faculty in the US value interdisciplinary more than disciplinary knowledge (Jacobs and Frickel, 2009, p. 46).

${ }^{2}$ For a critical view on the relevance of pro-interdisciplinary university policies in liberal arts disciplines, see Jacobs (2014), especially chapter 10 .

${ }^{3}$ There are of course exceptions: US universities such as Arizona State University (see Jacobs, 2014, p. 214) or Stanford University have entirely restructured their organizations around interdisciplinary education and research areas.
} 
accompanying university interdisciplinarity in France to be (as in the US), a joint product of several types of actions from faculty members and/or in response to university policies. Indeed, such diverse efforts towards interdisciplinarity - as well as the resultant alliances and conflicts - reflect the definition of both countries' universities as pluralistic organizations with diffuse power, divergent objectives and knowledge-based work (Denis, Langley, \& Rouleau, 2007), as well as entrepreneurial universities where entrepreneurship is defined as an organizational effort to pursue opportunities via means beyond those that are currently available (Clark, 1998). In France, as in the US, some university leaders (presidents, vice-presidents, chancellors and vice-chancellors) are crucial promoters of interdisciplinarity and initiate proactive policies in order to redraw university departments' boundaries. But faculty members' fund-raising activities also impact universities' disciplinary and/or interdisciplinary organizations. In particular, academics who succeed in attracting large grants for interdisciplinary research tend to be allowed increased autonomy by their disciplinary departments, and may also use their stronger positions as bargaining resources in their negotiations with other departments or with their universities' presidential teams (Paradeise, Noël, \& Goastellec, 2015).

This chapter seeks to compare the organizational changes brought about by the development of interdisciplinary research in French and US universities, as well as the university policies that initiate or support these changes. Our analysis is non-prescriptive (i.e., we are not looking to identify 'best practices' to promote interdisciplinarity), but rather seeks to highlight issues of articulation and alignment between the different types of actions underlying the development of interdisciplinarity at individual universities. In which university settings does interdisciplinarity lead to organizational change? What roles do university policies play in these changes? How do interdisciplinary initiatives relate to each other and fit into universities' overall strategies? We address these issues via a qualitative approach, analyzing the implementation of interdisciplinary nanomedicine in five leading French and US research 
universities. ${ }^{4}$ We focus on interdisciplinarity in research and in post-graduate education, and identify three situations where shift in organizational structure occur: in principal investigatorbased research teams; in departmental boundaries; and in institutional structures. For each setting, we identify the key promoters of interdisciplinarity (university leaders, department heads , faculty members, funding agencies, policy makers, etc.) as well as their associated objectives and the organizational issues involved in their interdisciplinary endeavors (such as governance, leadership and resource allocation). We conclude the chapter by summarizing the major similarities and differences between the organizational shifts associated with the implementation of interdisciplinarity at the French and US universities we studied.

\section{Literature review}

Many authors who have defined interdisciplinarity have differentiated it from other concepts, such as multidisciplinarity and transdisciplinarity. They usually agree that, while multidisciplinarity involves the simple juxtaposition of knowledge between disciplines, and transdisciplinarity implies the integration of knowledge across several disciplines, interdisciplinarity refers to a situation where two (or more) disciplines engage in dialogue and in complementary activities to the extent that they can transform not only those disciplines themselves but also the boundaries between them (Barry, Born, \& Weszkalnys, 2008; Weingart $\&$ Stehr, 2000). There is a long-standing debate about whether interdisciplinarity questions the centrality of disciplines themselves, defined both as the cognitive and instrumental repertoires shared by research communities and as social organization patterns via which contemporary sciences develop and validate new knowledge. While some authors argue that interdisciplinarity is needed to counter the increasing domination of contemporary scientific specialization

\footnotetext{
${ }^{4}$ The author - who collected the empirical data in California while a visiting scholar at UC Berkeley Center for Science, Technology, Medicine and Society - acknowledges support from the ANR: Nanoexpectation project (ANR-09-NANO-032; programme in Nanosciences, Nanotechnologies and Nanosystems P3N2009); Hybridtrajectories project (ANR 2010 Blanc - 1811 - 01).
} 
(Bonaccorsi, 2010; Lenoir, 1997) and to foster breakthrough innovations (Dogan \& Pahre, 1991), others claim that the intellectual breadth of disciplines - as well as their internal differences - enables constant innovation (Jacobs, 2014).

Despite these debates, interdisciplinarity has become commonplace in science public policy over recent decades, with policy makers seeing it as a way to counter excessive academism in science. The political discourse on interdisciplinarity, which promotes logics of "accountability" and "innovation" in the public sciences (Barry et al., 2008), reached a climax in the $1990 \mathrm{~s},{ }^{5}$ with the call for a 'Mode 2 ' of knowledge production, in which scientific research would be structured around problems to be solved in the real world (climate change, cancer, etc.) rather than around disciplines (Gibbons et al., 1994). This positive discourse about interdisciplinarity resulted in widespread efforts from research sponsors (funding agencies, local authorities and firms) and university leaders to promote it. The rise of interdisciplinary initiatives has also led to the emergence of its own research field, especially with the publication of handbooks listing interdisciplinary actions taken by universities or in several scientific areas, and dealing with how to overcome obstacles to interdisciplinary research - see for instance, Frodeman, Klein, \& Mitcham (2010). Some authors have also taken a critical stance towards interdisciplinary policies: they either show that the assumptions underlying the claims for their benefits are not being sufficiently questioned (Jacobs \& Frickel, 2009), and that traditional disciplines also have a high innovation potential (Jacobs, 2014), or they observe a certain degree of decoupling between pro-interdisciplinary policies -emphasizing synergies between disciplines - and interdisciplinary practices - where certain disciplines still impose their working methods and their evaluation standards (Albert, Paradis, \& Kuper, 2015; Louvel, 2015). Many

\footnotetext{
5 One should however note that interdisciplinarity has a long history in disciplines as diverse as education, gerontology, feminist studies, organization studies and public policy (Brint, Turk-Bicakci, Proctor, \& Murphy, 2009, p.156), areas in which it was meant to encourage both economic and social innovation.
} 
analyses have been conducted addressing these issues in two settings. ${ }^{6}$ First, the interdisciplinary university research centers that have multiplied in the last three decades in the US - mostly with the support of the National Science Foundation and the National Institutes for Health (Etzkowitz \& Kemelgor, 1998; Geiger, 1990; Stahler \& Tash, 1994)- have been investigated in multiple dimensions: their effects on researchers' productivity (Sabharwal \& $\mathrm{Hu}, 2013$ ) and on scientists' collaborations (Boardman \& Corley, 2008); their levels of institutionalization as assessed e.g. by resource allocation procedures, setting research agendas (Youtie et al., 2006) or effective knowledge management (Boardman \& Ponomariov, 2014; Ponomariov \& Boardman, 2010). Interdisciplinary research has also been investigated as a set of organizational and managerial challenges undertaken by numerous US universities. Scholars have analyzed how university leaders try to weaken the authority of disciplinary departments with the goal of "creating the future" (Brint, 2005, p.38), rather than reaching excellence in traditional disciplines - e.g. by creating interdisciplinary graduate programs (Newswander \& Borrego, 2009) or by hiring faculty for interdisciplinary research reasons (Sá, 2008b). Those scholars who favor interdisciplinarity see the persistence of disciplinary departments as being anchored in institutional cultures and as principally serving established academic arrangements or political interests (Sá, 2008a). They argue that successful interdisciplinary university policies facilitate "transformational change" i.e. change that is "pervasive, intentional, which occurs over a period of time, and has a strong influence on institutional culture” (Holley, 2009, p. 334). Critical scholars warn that "anti-disciplinary" university policies - e.g. the organization of universities around flexible interdisciplinary arrangements - will increase the fragmentation of the sciences and focus research only on short-term objectives (Jacobs, 2014).

These numerous studies have shown the importance in the US context of two loci of

\footnotetext{
${ }^{6}$ American scholars have been remarkably active in the formation of the field of interdisciplinary studies, but European scholars have also taken an early interest in this topic (Boutier, Passeron, \& Revel, 2006; Vinck, 2000).
} 
organizational change (university research centers and university policies), and addressed issues of their articulation. However, one can wonder whether interdisciplinarity raises similar organizational and managerial problems in other contexts, particularly in European universities - which, indeed, also display several loci of organizational change. First, European universities are transforming themselves into "organizational actors" (Brunsson \& Sahlin-Anderson, 2000) with strategic capacities to implement pro-interdisciplinary policies. As in US universities, these change strategies are often co-constructed between university leaders and departmental faculties (Gioia \& Thomas, 1996; Jarzabkowski, 2008; Louvel, 2013; Townley, 1997) - in particular, deans (heads of departments) are often central actors in the elaboration of university strategies (De Boer \& Goedegebuure, 2009). Moreover, European universities are fragmented or "pluralistic" organizations (Denis et al., 2007), composed of collectives (departments, research labs, research centers, etc.) each pursuing their own objectives, which may have conflicting views and expectations about and towards the university. These entities may also collaborate with - and seek funding from - commercial companies, local authorities, funding agencies, or foundations for interdisciplinary research. Their activities impact the universities' organizational structures in ways that are not directly addressed by university leadership teams, nor always explicitly integrated in their strategic plans, but are aligned with the notion of European universities as entrepreneurial actors (Clark, 1998).

How does the development of interdisciplinary research in European universities combine initiatives taken by university leaders, deans and faculty members? What are the main loci of organizational change? How do interdisciplinary initiatives fit into universities' overall strategies? To address the specific organizational issues encountered by US universities, this chapter compares the development of interdisciplinary nanomedicine at French and US universities. 


\section{$3 \quad$ Method}

\subsection{Nanomedicine as a showcase for interdisciplinary research and post-graduate education}

We focus our empirical study on research and post-graduate education in nanomedicine, which can be broadly defined as the application of nanotechnology to biomedical problems. Nanomedicine is often presented as an archetypal setting for scientific interdisciplinarity, associating - depending on the focus of the research project involved - cell and molecular biology with chemistry (synthesis and characterization of nanoparticles), pharmacology, applied physics (study of mechanical properties, with molecular and cell signaling), bioinformatics (simulation of molecular systems, design of molecules), electrical engineering (imaging technologies), material sciences (design of devices), etc. As in other interdisciplinary areas of the biomedical sciences, nanomedicine carries high expectations, both in clinical and economic terms, and so has been supported by massive efforts in many countries worldwide over recent years which have provided many opportunities to structure interdisciplinary research in the form of projects, networks, research centers, post-graduate programs, etc.. Thus, considering nanomedicine opens a window to look more broadly at interdisciplinarity in the contemporary life-sciences.

Some of these initiatives focus on nanomedicine as such, providing funding for interdisciplinary research labs and centers. The US was probably the first country in the world to promote interdisciplinary nanomedicine centers as part of the National Nanotechnology Initiative (NNI), a federal policy launched in 2000 which benefited from a cumulative investment of $\$ 18 \mathrm{Bn}$ by 2013. ${ }^{7}$ The National Institutes of Health (NIH) have contributed to the NNI by supporting the institution of eight Nanomedicine Development Centers (NDCs) since 2005; by initiating calls

\footnotetext{
${ }^{7}$ Source: http://www.nano.gov/about-nni/what/funding. 100 interdisciplinary education and research centers were created as part of the National Nanotechnology Initiative. 24 of them are nanomedicine related: http://www.nano.gov/centers-networks.
} 
for tenders for research on Nanoscience and Nanotechnology for Biology and Medicine; and by launching sectorial initiatives, such as the Alliance for Nanotechnology in Cancer by the National Cancer Institute (NCI) in 2004. But nanomedicine has also benefited from funding from the Departments of Energy and of Defense, as well as from universities and local authorities. Subsequently, European countries have launched similar nanomedicine programs (e.g., the French national research agency's Nano-Innov initiative launched in 2009, and programs within the EU's Framework Programs 6 and 7). At the same time, nanomedicine has benefited from larger funding programs aiming at developing interfaces between biology and other disciplines, including chemistry, material sciences, physical sciences, and engineering sciences.

However, very few specific nanomedicine departments have been created at either US or French universities. Rather, nanomedicine research has been hosted by well-established departments (such as molecular and cellular biology, pharmacology, chemistry, material sciences) and/or by newly created interdisciplinary departments (in particular, biomedical engineering, which covers research areas combining biomedical and engineering sciences such as nanomedicine, but also areas such as synthetic biology).

\subsection{A case-study approach in French and American universities}

We adopt a case-study approach across several universities in order to explore the organizational issues thrown up by interdisciplinary endeavors and reveal the in-depth, situated knowledge about the organizational choices taken by faculty, deans and university leadership teams. For this study, we chose universities from France and from the US which are regarded as leaders in the nanoscience area, and more specifically in nanomedicine (considered in terms of research funding, publications and patents). We do not particularly question the reasons for this leadership - rather this criterion ensures that the universities chosen as case-studies have 
critical mass in nanomedicine. Our case study universities also all have interdisciplinarity in their mission statements - although they operationalize this concept differently.

The material used in this chapter mainly comes from an empirical study of two French universities (Grenoble and Toulouse) ${ }^{8}$ and three in the US (UC Berkeley, UC San Francisco, and UT Houston), although we also include occasional examples from other universities (e.g. UC Davis, UT Austin or Rice University) in our overall study. Our source material comes from in-depth interviews conducted with academics (vice presidents, heads of departments, heads of research centers, faculty members, as well as relevant documents (reports, press releases, web sites, etc.). For the purposes of this chapter we use 50 interviews conducted over a 4 year period (2009-2013), ${ }^{9}$ and focus on those parts of the interview material that concern the organizational changes that accompanied the rise of interdisciplinarity in those settings. Data coding was inductive and guided by the following research questions: At which university levels is interdisciplinarity gaining importance? To what extent does it alter existing organizational structures, and in particular departmental boundaries? What are the respective roles of faculty and university managers in its development? In which areas do actors involved in these interdisciplinary endeavors collaborate or conflict? Data analysis leads us to identify three particular settings of organizational change (research teams, departments and institutional structures) and to differentiate them according to five dimensions: the promoters of interdisciplinarity; the objectives associated with it; the tools for its implementation; the organizational changes involved; and the organizational issues (in terms of leadership, governance and resource allocation) associated with those changes. ${ }^{10}$

\footnotetext{
${ }^{8}$ At the time of our study, there were three universities in each city - one for STEM (Science, Technology, Engineering and Mathematics), one for social sciences and one for humanities. We conducted our empirical study at the two universities dedicated to STEM disciplines. For simplification's sake we refer to them as 'the University of Grenoble'/‘University of Toulouse'.

${ }^{9}$ Interviews in French universities were conducted by the author and by research assistants (A. Gonthier, M. Libersa and C. Mounet), and those in American universities by the author. All interviews were recorded, fully transcribed and thematically coded using N-Vivo software.

${ }^{10}$ See Table 1 in the Appendix for a summary of the results
} 


\section{Results: settings of organizational change; challenges and issues for university policies}

\subsection{Research teams: facilitating bottom-up dynamics}

The development of interdisciplinary nanomedicine research and post-graduate education in US and French universities stems first from the actions of principal investigators (PIs) of research teams acting as "quasi-entrepreneurs" (Etzkowitz, 2003), applying for competitive grants and recruiting staff (mainly $\mathrm{PhD}$ students and post-docs). These actions are major driving forces behind the growth of interdisciplinarity, but that does not always imply that such growth enjoys strong institutional support from the universities concerned. However it explains the vitality of interdisciplinary research, even in universities where disciplinary departments are very powerful. Interdisciplinary research can be considered 'science-driven', insofar as the central logic for creating such research teams is science oriented (in terms of the complementarity between the teams' different expertise; their expectations of making breakthrough innovations; and their hopes of overcoming competitors). Fluidity prevails over stability, as interdisciplinary cooperation is highly dependent on the availability of funding: indeed, most such interdisciplinary research teams are created and maintained via successful investigator-initiated grant applications. However, the conditions for awarding funding do not always seem to support interdisciplinary research - in particular, success rates for applications to major funding agencies have been decreasing in recent years, due to the growing number of applicants and (more recently) to funding cuts (e.g. NIH and NSF). For instance, success rates for applications to NIH were around 30\% in the 1980s (Stephan, 2012), but had fallen to $8.6 \%$ by 2012 (for first submissions for R01 equivalent grants ${ }^{11}$ ) - and even lower in certain study sections. Success rates for French ANR grants have decreased more slowly (from 25.7\% in

\footnotetext{
${ }^{11}$ R01 grants are non-targeted, investigator-initiated grants.
} 
2005 to $21.3 \%$ in 2011), but vary a lot between different funding calls. Such competition for grant funding hinders these science-driven interdisciplinary dynamics in two ways. First, despite official support for interdisciplinary projects from funding agencies, principal investigators prefer to locate their research efforts within single disciplines. Indeed, they have learnt (from previous unsuccessful applications or from their own experience of reviewing grant applications) that reviewers try to minimize the chance of selecting risky proposals, and so tend to give multidisciplinary applications - which are generally viewed as more risky than disciplinary ones, and about which there is usually greater disagreement between reviewers from different disciplinary backgrounds - lower scores (Lamont, Mallard, \& Guetzkow, 2006): "For the NIH, you almost have to be multidisciplinary now, you have to have a team, and you have to have more than one expertise at the same time. But when we have grant reviews, for example, many of the projects are so multidisciplinary that... it is hard to get people who understand [them]. There are experts on every single topic .... And you can't satisfy everyone. (...) And so when I sit down [to report] on NIH study sections, there are always problems [with interdisciplinary proposals]." (Biomedical engineering PI, UCSF)

"It's absolutely certain that the lack of research funding forces people to stick to their discipline and to areas where they are not taking any risks." (French physicist, Toulouse)

Second, even though funding bodies present interdisciplinarity as the only way to 'think outside the box' in emerging fields nowadays, nanomedicine PIs associate incentives for interdisciplinary research with a growing pressure to develop translational research, and see funding agencies as becoming less interested in basic science, i.e. investigations that are not directly linked to solving specific problems, but which can promote more general problemsolving approaches (Calvert, 2006). At the NIH, even though peer-reviewed, investigatorinitiated grants may not respond directly to specific health considerations (Sampat, 2012), all grant applications for investigator-initiated research have been obliged (since January 2010) to 
include a section on 'innovation'. Although the submission guidelines describe 'innovation' in very general terms ${ }^{12}$ PIs tend to interpret it as showing the potential of their research for clinical applications and as encouraging interdisciplinary collaborations between researchers and clinicians (toxicologists, pharmacologists, medical doctors, etc.). Furthermore, they feel pressured to practice translational research so as to bring basic science 'from bench to bedside' when seeking alternative funding from foundations and local authorities. These translational objectives can seem to contradict the idea of interdisciplinarity research as fostering scientific discoveries for the long term (Albert et al., 2015).

University leaders and department deans may have little control over the development and directions of such interdisciplinary teams. As can also be the case in disciplinary research, project-based research funding tends to be subject to centrifugal dynamics (with PIs being essentially connected to networks outside their institutions), so hindering universities' abilities to set science policy priorities. While autonomy has been a characteristic of PIs since the rise of US research universities in the $19^{\text {th }}$ century (Etzkowitz, 2003), it has gained importance in recent decades in French universities with the rise of project-based funding and the diversification of local, national and European funding sources (Louvel, 2010). But universities can play roles in supporting such interdisciplinary endeavors without weakening their disciplinary departments (in particular, neither withdrawing resources from them, nor transferring decision-making powers to university leaders). Both French and American universities facilitate the formation of interdisciplinary research teams by minimizing the risks

\footnotetext{
12 In January 2010 the NIH implemented a new format for its investigator-initiated grants. So far the grant applications had been 25 pages long and PIs wrote a "research plan" divided into 3 sections: Background \& Significance, Preliminary Studies and Progress Report, Research Design and Methodology. The new application is 12 pages long and the research plan is replaced by a section on 'research strategy' divided into Significance, Innovation and Approach. In the section on Innovation, applicants must: "Explain how the application challenges and seeks to shift current research or clinical practice paradigms; describe any novel theoretical concepts, approaches or methodologies, instrumentation or intervention(s) to be developed or used, and any advantage over existing methodologies, instrumentation or intervention(s); Explain any refinements, improvements, or new applications of theoretical concepts, approaches or methodologies, instrumentation or interventions" (U.S. Department of Health and Human Services Public Health Service, Grant Application (PHS 398): Part I I-46.)
} 
involved (e.g. by distributing 'seed grants' for which competition is less intense than for major grants from funding agencies). In France, national institutions also redirect a limited share of their resources towards interdisciplinary research. ${ }^{13}$ For instance, the largest French national research organization - the CNRS (Centre National de la Recherche Scientifique) - supports a few large nanomedicine labs (Unites Mixtes de Recherche) in undertaking interdisciplinary research, which receive funding and funded posts (both academic and technical staff). The CNRS also supports positions for tenured researchers doing interdisciplinary research, thus opening (albeit only a few) opportunity spaces for interdisciplinary careers. ${ }^{14}$

Finally, universities facilitate interdisciplinary collaborations which emerge bottom-up by supporting transverse structures that strengthen linkages between departments, but preserve their autonomy. The most flexible of such organizations are university networks, (e.g. the Berkeley Nanoscience Initiative (BNNI) and nanoscience research directories and websites at UC Davis and Grenoble), which both foster a sense of community among nanoscience researchers and increase the visibility of the field. Stimulated by a few academics, many universities (e.g. UT Austin, Grenoble) have also created shared nanoscience courses for PhD students, aiming both to deliver interdisciplinary training and to foster networking among students from very diverse backgrounds. The widespread practice of joint faculty appointments in American universities also integrates departments without affecting their separate resource allocations (with professors generally having ' $0 \%$ appointments' - neither getting paid by nor having any teaching duties - in departments outside their home disciplines). In some universities (e.g. UC Davis), departments associate in running interdisciplinary graduate groups (although

\footnotetext{
${ }^{13}$ These national institutions have traditionally supported the disciplinary organization of academia (Paradeise et al., 2015). For instance, the national body (le Conseil National des Universités) that allows French academics to apply for faculty positions (as assistant or full professors) is divided into 74 disciplinary sections.

${ }^{14}$ Most tenured CNRS researchers are recruited by disciplinary committees. However the CNRS has created four interdisciplinary committees, two of them intersecting with nanomedicine (the committee for Modélisation, et analyse des données et des systèmes biologiques: the committee for approches informatiques, mathématiques et physiques)
} 
some still organize their own disciplinary programs) in order to gather a critical mass of doctoral students. Other universities create umbrella organizations over departments, not replacing them but increasing students' opportunities to rotate between labs and their course choices (e.g. the Department of Biomedical Engineering which encompasses three Texan campuses). ${ }^{15}$

In a sense, interdisciplinary research teams form 'liminal spaces' within universities where faculty can initiate interdisciplinary collaborations and interact over limited periods. University policies mainly aim at facilitating bottom-up dynamics rather than at institutionalizing interdisciplinary spaces. By contrast, a second type of interdisciplinary initiative aims at redrawing departmental boundaries - which are usually discipline-based.

\subsection{Departments: weakening the links between departments and disciplines}

Reforms of universities' departmental organizations are usually driven by several objectives such as enhancing the university's capacity to innovate in interdisciplinary areas, or orienting education and research towards priority business and societal areas - with the hope of generating revenues from partnerships with commercial/industrial organizations as well as from tuition fees. Such reforms are promoted and driven by deans and university leaders in alliance with 'entrepreneurial academics'. They can raise issues of governance when they are associated with centralized decision-making processes (in the hands of university presidential teams imposing reforms on departmental deans acting with or without the support of other departments) as well as of resource allocations between departments. Lastly, such projects benefit from external support - which helps them gain legitimacy to address organizational issues. In the US universities we studied, such support was provided by external sponsors (foundations, local authorities and companies) funding interdisciplinary research and post-graduate education in

\footnotetext{
15 The University of Texas at Austin, The University of Texas Health Sciences Center at Houston and The University of Texas MD Anderson Cancer: http://www.utexas.edu/news/2006/05/17/engineering/
} 
the life-sciences. In the French universities, organizational restructuring was facilitated by changes in the national higher education and research policy set by the French ministry, which increased universities' self-governing capabilities (Musselin, 2004).

\subsubsection{Support from external sponsors in US universities}

The Health Sciences Initiative, launched at UCB in $1999,{ }^{16}$ is an interesting example of entrepreneurial academics building on external support and allying with university leaders to fight against the organizational fragmentation of the university and to target emerging interdisciplinary research themes. First, in this case, interdisciplinarity aligns with the centralization of certain decisions and the setting of scientific priorities by university leaders. This initiative took over interdisciplinary university policies from the 1980s when "the campus reinvented the biological sciences by merging fields including anatomy, physiology, microbiology and zoology into three 'integrative' departments" (UCB Chancellor Robert M. Berdahl, Press release, 10/6/1999). The creation of interdisciplinary life-sciences departments relied on the lobbying efforts and proactivity of "institution builders" (Jong, 2008), such as Robert Tjian (a Professor in the Department of Cell and Molecular Biology) who convinced the university administration that the organizational fragmentation of biology was a major obstacle to the rise of biotechnology research, and Daniel Koshland (a Professor in the Biochemistry Department) who designed the outlines of the 'integrated departments' in the early 1980s, and suggested giving universities' administrations more decision-making power over faculty recruitment so as to target appointments towards their priority areas. Both these 'institution builders' encountered considerable opposition from several departments, but their strong links with the biotech industry gave their ideas legitimacy with the UCB university administration.

\footnotetext{
${ }^{16}$ A $\$ 500$ million initiative (which included $\$ 100$ million in private gifts and \$24 million of state support) aimed at "redefining health science research by uniting physical and biological scientists and engineers" (News release 10/6/1999 - public affairs, (510) 642-3734)
} 
Second, the UCB Health Sciences Initiative relied strongly on external sponsors. In particular, the Biomedical Engineering Department created in 1998 - which hosts part of nanomedicine research - was given $\$ 15$ million from the Whitaker foundation in $2000 .{ }^{17}$ These newly created departments gained legitimacy both from this external funding, and from their ability to attract students as well, so as to raise revenues from partnerships with biotechnology industry and pharmaceutical companies. These two characteristics, as well as the prospect of possible spillovers from and into other departments, are important for preserving biomedical engineering departments' legitimacy over the long term, as - after the initial impetus from the Whitaker Foundation's start-up finance - they have to compete with other engineering departments for university positions and funding:

"Traditionally-minded engineers may have visceral reactions about biology... [perhaps] they view [it] as a softer science [than] traditional engineering, they don't feel that it has a place in engineering schools certainly, at the level of legitimacy of a formal department." (Bioengineer, UC Berkeley)

In other universities, such interdisciplinary policies are not oriented so much towards breaking down perceived disciplinary 'silos' as to raising the university's profile in a highly competitive research area. This is the case at UC San Francisco, which, over a few decades, has become a world-class health science campus by supporting interdisciplinarity (Bourne, 2011). New developments in the life-sciences (such as nanomedicine) require extending the university's established disciplinary spectrum to disciplines such as physical sciences and computer sciences:

"We have no physics department, no engineering department. And so we need to be able to attract physicists and engineers, chemists, mathematicians, to look at USCF as a great place for them to work, for their careers, [but] there is no department, there is

\footnotetext{
${ }^{17}$ Source: closing report of the Whitaker foundation, 2005. Approximately 30 such interdisciplinary departments were created in American universities in the 1990s and 2000s with financial support from the Whitaker foundation. In contrast, European universities have not benefitted from such outside patronage, and so have almost no biomedical engineering departments.
} 
nothing that looks traditional to them." (Cell and molecular biologist, Vice-Chancellor for Research UCSF)

Creating specific interdisciplinary departments does not appear to be a suitable strategy as, by themselves, they do not attract enough students to open stand-alone undergraduate curricula. So the university leadership has strengthened interdisciplinarity between existing departments by enlarging their scientific boundaries and allocating faculty positions: for instance, the Department of Therapeutic Sciences has become the Department of Bioengineering and Therapeutic Sciences - the first joint department between UCSF schools of medicine and pharmacy - and now recruits both physicists and bioengineers. UCSF has also created transverse structures (such as inter-departmental or inter-school experimental platforms and doctoral programs) which have weakened the powers of traditional departments in terms of resource allocation and enabled researchers from minority disciplines to belong to inter-departmental groups. Lastly, UCSF has partnered with UCB to create a joint bioengineering graduate $\operatorname{program}^{18}$

\subsubsection{Pro-interdisciplinary policies fostered by the "institutional empowerment" of French universities}

The French universities we studied have also both merged departments or grouped them into federal interdisciplinary structures. In these cases, fund-raising from entrepreneurial academics and university leaders has also played a role, even though the funds raised are much lower than in US universities. Moreover, such fund-raising for interdisciplinary reorganizations is developing as a result of the strengthening of French universities" "self-governing capabilities" (Musselin, 2004) and by the "institutional empowerment of French universities" (Musselin \& Paradeise, 2009, p.28) - an incremental process that began in the 1990s and accelerated after

\footnotetext{
${ }^{18}$ A similar association can be found in Texas with the graduate biomedical sciences program between UT Houston and MD Anderson.
} 
the adoption of the "Loi sur la responsabilité et l'autonomie des universités" (The Law on Liberties and Responsibilities of Universities) in 2006. In this context, French University leaders rely on multiple policy instruments to redraw departmental boundaries. Since as early as the 1980s and 1990s, they have received funding for interdisciplinary research and education when negotiating their university budgets with the higher education Ministry and the regional authorities. ${ }^{19}$ In the 2000s, some universities ended departments' monopolies on doctoral training by taking advantage of the French higher education Ministry's requirement to create interdisciplinary doctoral schools (which organize doctoral training, distribute doctoral funding and award doctoral titles). More recently, under the impulse of the new legislation (2006) which gives them financial and operational autonomy, some universities have also designed global research strategies in which interdisciplinarity and collaborations between departments are a priority. In Grenoble, university leaders and departmental deans have used these various means to promote interdisciplinarity between physics and life sciences, and between physics and chemistry. This policy has also involved creating a large graduate school covering chemistry and biology, launching a major interdisciplinary program on 'new physical approaches in the life sciences' (funded by the Ministry and the Region through a 2000-2006 State-Region plan worth $€ 2.29$ million), and funding new buildings to house these interdisciplinary research initiatives. Lastly, all university research activities in STEM (Science, Technology, Engineering and Mathematics) fields have been grouped since 2007 into four interdisciplinary 'pôles' or clusters - umbrella organizations located above the 17 disciplinary departments governed by boards composed of representatives from the pôles' research labs. The university research policy is defined by a board that brings together the four pôle leaders, has a dedicated

\footnotetext{
${ }^{19}$ Since 1984, universities have negotiated four- and five-year budgets with the Ministry and regional authorities via State-Region plan contracts (Contrat de plan Etat-Région).
} 
budget for interdisciplinary projects (including nanoscience) ${ }^{20}$ and sends its research priorities for new faculty positions to the academic senate. The University of Toulouse structure has undergone a similar reform, with the creation of four interdisciplinary research pôles - again above departments - in 2008. In both universities, these initiatives have been accompanied by strengthened managerial logics that emphasize formal objectives and performance indicators. In Grenoble, the establishment of these interdisciplinary research pôles has also allowed for the co-construction of science policy between some faculty members - in particular, the directors of large research labs - and university leaders, and thus has tended to reduce the authority of departmental deans and (to some extent) academic senates.

In France, interdisciplinary university policies are developing in a context in which the French ministry has moved away from the "faculty-focused character of university education steering" (Musselin, 2004, p. 67) and recognizes the legitimacy of university presidential teams for defining overall strategies. But French universities gain most of their financial room for manoeuver for developing such interdisciplinary policies from grants and contracts, and so - as in the US - depend on fund-raising activities undertaken by faculty.

Lastly, the third type of organizational change involves the creation of large-scale interdisciplinary research organizations that are institutional structures (bringing together several universities and/or research institutions, and supported by funding agencies, local authorities and/or firms). These organizations include university-based research centers in the US and large-scale university-based research projects in France. While US and French initiatives show high degrees of diversity in terms of organizational forms, governance structures and funding models, many of them mobilize the same actors ('entrepreneurial' academics, deans and university leaders from several universities), who build alliances between

\footnotetext{
${ }^{20}$ In 2008 , this budget amounted to $€ 3$ million (9.1\% of the universities' total research budget): it had quadrupled since 2005 as a result of increases in universities' resources from grants and contracts (source: Report from the French National Evaluation Agency -AERES-, 2010, p1).
} 
their institutions to leverage funds. While the French universities studied respond to demands from the French ministry of higher education and research, they are also motivated to form interdisciplinary alliances to represent themselves as world-class universities, encompassing all knowledge areas and having high international visibility (Musselin \& Dif-Pradalier, 2014, p.287).

\subsection{Institutional structures: forming large-scale interdisciplinary research organizations}

These large interdisciplinary research organizations focus on research but include other components such as training, technological transfer, and, in the biomedical sciences, translation to clinical settings. They also imply some kind of geographical concentration on one campus, although not all the participating institutions may necessarily be co-located. They serve several interrelated policy objectives, such as attracting large amounts of funding but avoiding having to disperse it between large numbers of beneficiaries; reaching a critical mass for research in a given area; fostering the development of emerging and interdisciplinary sciences considered of high economic and social relevance. They usually distribute grants, facilitate interdisciplinary team-building and/or give access to shared facilities.

\subsubsection{Joint fund-raising efforts from faculty and university leaders in French and US universities}

Large-scale interdisciplinary research organizations result from efforts to leverage funding for interdisciplinary research in particular areas and/or given territories (a campus, a city - or even a state in the US). Such fund-raising efforts are generally cumulative, either in the sense that funding for such projects is too large to be provided by a single sponsor, or that initial funds open opportunities for subsequent finance (e.g. a small grant from a funding agency or a university seed-grant enables researchers to prepare for a larger grant application). 
Nanomedicine research has developed from such initiatives in all the cases studied in France and the US. For instance, the Texas Center for Cancer Nanomedicine ${ }^{21}$ a research center of the National Cancer Institute (NCI-NIH) which gathers five partner institutions, results from at least three fundraising steps. First, the lobbying efforts of faculty members, deans and university leaders from several Texan universities led to the constitution of the Alliance for NanoHealth (ANH) in Texas, which subsequently received major funding from the State of Texas and the U.S. Congress: ${ }^{22}$

"We worked closely with our politicians in the Houston area who helped us get Congress [grants earmarked for this project]. And we have been able to garner something like $\$ 27$ million of federal support for the Alliance for NanoHealth [over its first four years]." (Chemist, co-PI for ANH, UT Houston)

During the same period, these entrepreneurial academics launched parallel fund-raising efforts aimed at foundations: for example, the Gulf Coast consortia (GCC), which gathers Texan universities around research conducted at the interface between the biomedical sciences and the hard physical sciences, is funded by the Keck and Dunn foundations. Finally, both the ANH and the GCC prepared applications to the NCI's competitive Alliance for Nanotechnology in Cancer call: ${ }^{23}$

"A NCI Centre grant often requires demonstration of continued funding, of funded research that can then be synergised by bringing together two or three different projects. The fact that we had multimillions of dollars to give small grants to catalyze research among people ... as well as to foster infrastructure and support was a very big factor [in the success of the Texas Center for Cancer Nanomedicine]." (Chemist, co-PI

\footnotetext{
${ }^{21}$ The partner institutions are: the University of Texas Health Science Center; Duke University; The Methodist Hospital Research Institute; Albert Einstein College of Medicine. Source: http://nano.cancer.gov/action/programs/uthsc/

22 The ANH is a consortium of 6 institutions: Baylor College of Medicine, the Methodist Hospital Research Institute, Rice University, Texas A\&M Health Science Center, The University of Texas Health Science Center at Houston, The University of Texas MD Anderson Cancer Center, and The University of Texas Medical Branch at Galveston. Source: http://alliancefornanohealth.org/.

${ }^{23}$ The Alliance for Nanotechnology in Cancer centers are funded under NIH requests for applications (RFAs) which are "more political and more applied funding mechanisms" (Sampat 2012 p. 1735) than other awards, such as RO1 grants.
} 
for ANH, UT Houston).

Fundraising in California (and in Grenoble and Toulouse) was not directed towards creating a single large interdisciplinary nanomedicine research center: rather such efforts were multiple initiatives that either targeted nanomedicine, or wider biomedical research areas (such as cancer research), or life-science approaches. This was the case for the California Institute for Quantitative BioSciences (QB3), which was created in 2000 by academics from UC Berkeley, UC Santa Cruz and UCSF, and was mainly sponsored by the State of California and by biotechnology companies. Other similar initiatives in California include the Synthetic Biology Institute at UC Berkeley (SBI) created in 2011 between UC Berkeley and the Lawrence Berkeley National Laboratory with the aim of attracting industrial funding; and the Synthetic Biology Engineering Research Center (Synberc) founded by the National Science Foundation in 2006 in association with UC Berkeley, UCSF, MIT, Harvard, and Prairie View Agriculture and Mining.

In Grenoble, the Nanobio project, dedicated to fundamental research in the nano-biosciences, was sponsored by the university and CNRS, but also by regional authorities (which contributed $€ 25$ million between 2001 and 2004). The Clinatec project, launched in 2009 and aimed at developing translational research at the crossroads between nanotechnology and neurosciences, also gained significant finance (50\% of its funding) from regional authorities and from research institutions (mostly CEA). Toulouse has three interdisciplinary research centers which include nanomedicine. The InnaBioSanté foundation (Infotechnologies, Nanotechnologies, Biotechnologies, Santé) was created in 2006 with national funding ( $€ 8$ million from the French Ministry and the National Research Agency - ANR) as well as industrial funding from regional companies ( $€ 13.5$ million from an oil company and from health companies). The ITAV initiative (Institute for Advance Technologies in the Life-sciences) launched in 2011 by the CNRS, the INSA engineering school and the University of Toulouse, gathers technological platforms and 
projects. Lastly, the Cluster on Cancer Research (Pôle de Compétitivité Cancer BioSanté) gathers representatives from regional authorities, companies, research labs and higher education institutions from the Toulouse region to fund interdisciplinary research projects.

These French and US interdisciplinary projects are all deeply rooted in the dynamics of local cooperation and actions, so their progress may largely depend on the will of partner institutions to join forces and to negotiate. Even if university departments and research labs benefit from them (e.g. by having access to shared research facilities financed through these large research centers), they may also consider them as competitors for certain university resources (principally for technical staff and faculty positions). In particular, such conflicts may develop over university leaders' choices of priority interdisciplinary areas, as most universities do not have enough resources to invest in several large interdisciplinary projects at the same time (Jacobs, 2014).

\subsubsection{French universities complying with ministerial policies and aiming to achieve world-class university status}

In France, interdisciplinary and institutional cooperation is also expanding in order to reduce the high level of fragmentation of higher education and research efforts. Historically, many French campuses have been constituted by amalgamating autonomous institutions (universities, research institutions, grandes écoles, etc.). Cooperation between and/or integration of research and education structures are now central requirements of the French ministry for higher education and research. But French university leaders also believe in the value of cooperation and integration in helping them become world-class universities (Musselin \& Dif-Pradalier, 2014). The rhetoric of interdisciplinarity facilitates the union or merging of the curricula of different institutions, which can then offer their students a wider range of complementary areas of study. In particular, joint interdisciplinary curricula have multiplied at the postgraduate level: for example, between 2007 and 2010 the University of Grenoble and the Grenoble Institute of 
Technology (an engineering school) jointly organized and delivered 42 masters' degrees. ${ }^{24}$ Such instances of cooperation often stem from 'bottom-up' initiatives led by faculty members and supported by university leaderships, which see them as ways to rationalize the provision of on-campus training. However they are highly dependent on policies of cooperation between universities being in place - thus, the number of joint masters' degrees offered by these two Grenoble institutions fell from 42 to 16 during the 2011-2014 period, due to conflicts about how the institutions should share costs and revenues, as well as increasing competition for students.

Institutional cooperation around interdisciplinary projects has become almost mandatory since the Ministry of Higher Education and Research launched the Investissements d'avenir national science and innovation policy in 2010. The program is composed of several competitive calls for tender that oblige research groups, higher education and research institutions, and campuses to compete for funding. These funding mechanisms were designed to establish so-called 'excellent' university campuses, which would then gain high ratings in international university rankings, an objective stressed clearly in a report designing this policy. ${ }^{25}$

"To support the transformation of a limited number (five to ten) groups of higher education and research institutions (...) into interdisciplinary institutions of global size and reputation, with the aim of getting them included in the top fifty universities in different world rankings." (p. 56) "The projects submitted [for funding] (...) must involve groupings of several partners to form interdisciplinary ensembles characterized by their excellence" (p. 58). ${ }^{26}$

Interdisciplinarity and institutional cooperation (including mergers between several higher education and research institutions, as the term 'groupings' above suggests) are presented as two interrelated requirements to reach such 'excellence'. So, even if these keywords are not

\footnotetext{
${ }^{24}$ Including Masters in nanoscience and nanotechnology.

${ }^{25}$ A. Juppé and M. Rocard: “Investir pour l'avenir. Priorités stratégiques d'investissement et emprunt national”. Report to the French Président, La Documentation Française, Novembre 2009.

${ }^{26}$ A. Juppé and M. Rocard (2009) op. cit. - our translation
} 
presented as conditions of eligibility in the tender calls, they appear to operate as criteria for success. For example, the LABEX call (Laboratoires d'Excellence) launched in 2011 to fund scientific consortia stipulates that:

“.... research entities applying should gather, in their geographic areas, those organizations that are most active in their research topics" and that "thematic concentration, interdisciplinary openness and research at the borders of disciplines will be considered as important strengths" $(p .6) .^{27}$

Calls for projects can pose very different governance problems, as they aim to structure scientific consortia (e.g., the LABEX and EQUIPEX - Equipement d'Excellence - project calls) or groups of universities and research institutions (e.g., the IDEX - Initiative d'Excellence project call) in different ways. The LABEX and EQUIPEX calls often build on previous interdisciplinary collaborations. In Grenoble, the LABEX-funded project $A R C A N E,{ }^{28}$ set up to develop research at the interfaces between chemistry and biology, extends the partnerships built for the Nanobio program (see above). However, the LABEX and EQUIPEX projects differ from previous fund-raising actions in that they have to fit into the university's overall strategy - in fact, it is the university leadership (and not principal investigators) that submits the applications, and can choose to support them more or less actively.

IDEX projects mobilize leaders of higher education and research institutions, relying differently (depending on the case) on university bodies, department deans or ad-hoc project teams (Mignot-Gérard, 2009). Interdisciplinarity is central to the scientific dimension of IDEX projects, and has to be organized at the institutional level. IDEX projects also include essential governance requirements, which again have to be institutional. This is not the first time that the French Ministry has encouraged higher education and research institutions to group (see the post-2006 creation of PRES, or the higher education and research pôles). However the scale of

\footnotetext{
${ }^{27}$ Présentation 2011 de l'ANR sur l'objectif des LABEX

${ }^{28} \mathrm{https}: / / \mathrm{www}$.labex-arcane.fr/fr/content/laboratoires-excellence-arcane
} 
the financial issues (funding for IDEX projects can reach $€ 1 B n$ ) may push universities to regroup - or even to merge - to comply with the institutional pressures involved.

The successful application by Toulouse higher education and research institutions to the 2012 IDEX call relied on a highly interdisciplinary project built on previous collaborations (interdisciplinary postgraduate training, and interdisciplinary 'strategic thematic' or 'transversal' actions), and on a radical reform of university governance (that resulted in the creation of the federal University of Toulouse-Midi-Pyrénées in October 2014, which gathered together all the region's higher education institutions). In contrast, Grenoble University's IDEX application failed twice (in 2010 and 2012), stressing the importance of governance issues in these very large interdisciplinary projects. While Grenoble's applications benefited from very rich interdisciplinary collaborations associating several institutions (joint research groups, joint-masters, and the mergers of all the region's doctoral schools in 2009, and of several LABEX projects, etc.), both failed on governance issues (e.g., conflicts about whether institutions should merge or confederate, and institutional ambitions to preserve monopolies on particular disciplines).

\section{Conclusion}

This chapter describes the diversity of the organizational arrangements under which interdisciplinarity is developing in French and American universities today. Using the example of nanomedicine, we show that interdisciplinary research and post-graduate education are being implemented at several levels (the research group, the department, the university, groups of higher education and research institutions). So their development is not entirely in the hands of university leaderships, but also relies on complementary - and sometimes joint - initiatives between faculty, deans and presidential teams who often negotiate interdisciplinary projects with funding bodies. 
Our analysis first leads us to play down the significance of national differences, but rather to stress the similarities between the entrepreneurial efforts of academics and university leaders who support the development of interdisciplinarity in our two focal countries. This observation differs from the viewpoints of other authors who see American universities - and more generally, the American public science system in general - as being more highly favorable to interdisciplinarity than those in other countries, because of the flexibility of US public policies, which can quickly dedicate budgets to fields that emerge outside traditional disciplines (Bonaccorsi, 2007), and the high degrees of reputational competition and of intellectual pluralism (Whitley, 2003) that incentivize researchers to take more risks in their studies. Moreover, the institutional autonomy of American universities is generally seen as giving them great leeway to initiate very proactive interdisciplinary policies. In contrast, French academia is usually considered as less favorable to interdisciplinarity, in particular because of the lower degree of its universities' institutional autonomy, given the steering of their decisions by ministerial policies and their dependence on national institutions which favor established disciplines over interdisciplinary areas. $^{29}$

However, interdisciplinary research in the life-sciences has been strengthened in the last two decades in all French and US universities studied for this chapter, which leads us to emphasize the similarity of the forces driving interdisciplinarity, and of the organizational changes that have accompanied the moves towards interdisciplinary research, in both countries. In particular, as research is increasingly funded via competitive calls that promote interdisciplinarity, we note the presence of multiple interdisciplinary teams, consortia and research centers on all the French and US campuses we studied resulting from fund-raising efforts by entrepreneurial academics. University leaders have also made interdisciplinarity a priority, which has translated into

\footnotetext{
${ }^{29}$ For instance, as explained above, French academic careers are partly managed by a national body (Conseil national des universités) which is structured in disciplines.
} 
incentives for interdisciplinary research, various attempts to weaken departmental boundaries, and joint fundraising initiatives with entrepreneurial academics. Probably what differentiates interdisciplinary universities in the two countries most is the role played by the French ministry of Higher Education and Research in the development of pro-interdisciplinary university policies - rather than the level of interdisciplinarity. In the three American universities studied, interdisciplinarity mostly develops via fundraising for interdisciplinary research projects (coconstructed by, and negotiated between, academics, university leaders and funding bodies). The bargaining power of faculty members reflects both the strength of the academic profession in American universities (Cousin \& Lamont, 2009), and its academics' ability to draw on external support to promote the interdisciplinary reorganization of the study of life-sciences.

However, significant differences can be identified between the studied universities, which reflect the weight of disciplinary departments and their scientific perimeters, and the universities' strategies. At UCSF, faculty members and university leaders agree that disciplinary departments do not suit the university's scientific objectives (which are centered on biomedical research) or its strategic positioning vis-a-vis its competitors - which are large comprehensive universities. In contrast, at UCB, interdisciplinary life-sciences have been implemented by a coalition of interests involving university leaders and entrepreneurial academics, which required the breaching of the disciplinary boundaries of departments that considered themselves threatened by interdisciplinary reorganizations.

Lastly, we should note that our case studies are not necessarily representative of all research universities in the US. Indeed, universities' institutional autonomy and the strength of the academic professions in the US mean that disciplinary departments remain very powerful, even if interdisciplinary research flourishes in some areas (Thoenig, 2015). In this case, faculties' interdisciplinary program initiatives are decoupled from university policies, which mostly remain disciplinary. The vitality of interdisciplinary research remains conditional on the 
availability of investigator-initiated grant funding. But on the contrary, some US universities have experienced a strengthening in their leadership, with university leaders introducing radical interdisciplinary reorganizations so as to leave their mark during their terms, so that "interdisciplinarity seems likely to result in a shift of power away from faculty toward the central administration of the university" (Jacobs, 2014, p.210).

In the French universities we studied, we found that the organizational changes associated with the development of interdisciplinary research also come from the co-construction and negotiation of such projects between academics and university leaders. But the main difference from US universities is that pro-interdisciplinary university policies have been supported by considerable changes in the steering universities have received from the French Ministry of Higher Education and Research in recent decades. Indeed, the increased self-governance capabilities that the Ministry has granted French universities (Musselin, 2004) have enabled their leaders to initiate political moves towards interdisciplinary research and to bypass the resistance of departments. Also, since the 2000s, the Ministry has distributed competitive funding for large institutional and interdisciplinary research projects, with the aim of increasing both the societal and economic relevance and the international visibility of French universities. This national policy has fostered the institutional restructuring of French universities around interdisciplinary projects, a political impetus that has created tensions. First, the resulting interdisciplinary reorganizations are not always aligned with the interdisciplinary scientific projects launched by local entrepreneurial academics, especially when they follow rationalization and cost reduction objectives. Second, there are sometimes contradictions between the governance objectives associated with this political stance - in particular, between strengthening the university's strategy and gathering several higher education and research institutions into more visible clusters with single governance structures - that hinder the integration of interdisciplinarity into a clearly defined institutional objective. Finally, it may be 
questioned whether this political impulse has really favored the development of interdisciplinarity in French universities. The overall answer for the two universities we studied is positive: local scientific communities and university leaderships have managed (after several years of conflicts and learning) to co-construct interdisciplinarity in ways that reconcile local scientific dynamics with the Ministry's governance and restructuration requirements. 


\section{References}

AAU (2005). Report of the Interdisciplinary Task Force. Washington, DC Association of American Universities

Albert, M., Paradis, E., \& Kuper, A. (2015). Interdisciplinary promises versus practices in medicine: The decoupled experiences of social sciences and humanities scholars. Social Science \& Medicine, 126(0), 17-25.

Barry, A., Born, G., \& Weszkalnys, G. (2008). Logics of interdisciplinarity. Economy and Society, 37(1), 20-49.

Boardman, C., \& Ponomariov, B. (2014). Management knowledge and the organization of team science in university research centers. The Journal of Technology Transfer, 39(1), 75-92.

Boardman, P. C., \& Corley, E. A. (2008). University research centers and the composition of research collaborations. Research Policy, 37(5), 900-913.

Bonaccorsi, A. (2007). Explaining poor performance of European science: Institutions versus policies. Science and Public Policy 34(5), 303-316.

Bonaccorsi, A. (2010). New Forms of Complementarity in Science. Minerva, 48(4), 355-387.

Bourne, H. R. (2011). Paths to Innovation: Discovering Recombinant DNA, Oncogenes, and Prions in One Medical School, Over One Decade: University of California Press Medical Humanities Consortium.

Boutier, J., Passeron, J.-C., \& Revel, J. (Eds.). (2006). Qu'est-ce qu'une discipline? Paris: Éditions de l'EHESS.

Brint, S. (2005). Creating the future: 'New directions' in American research universities. Minerva, 43(1), 23-50.

Brint, S. G., Turk-Bicakci, L., Proctor, K., \& Murphy, S. P. (2009). Expanding the social frame of knowledge: Interdisciplinary, degree-granting fields in American colleges and universities, 1975-2000. The Review of Higher Education, 32(2), 155-183.

Brunsson, N., \& Sahlin-Anderson, K. (2000). Constructing Organisations: The Example of Public Reform Sector. Organisation Studies, 21(4), 721-746.

Calvert, J. (2006). What's special about basic research? Science, Technology and Human Values, 31(2), 199-220.

Clark, B. R. (1998). Creating Entrepreneurial Universities: Organizational Pathways of Transformation. Guildford: Pergamon.

Cousin, B., \& Lamont, M. (2009). Les conditions de l'évaluation universitaire. Quelques réflexions à partir du cas américain. Mouvements.

De Boer, H., \& Goedegebuure, L. (2009). The changing nature of the academic deanship. Leadership, 5(3), 347-364.

Denis, J.-L., Langley, A., \& Rouleau, L. (2007). Strategizing in pluralistic contexts: Rethinking theoretical frames. Human Relations, 60(1), 179-215.

Dogan, M., \& Pahre, R. (1991). L'innovation dans les sciences sociales : la marginalité créatrice. Paris PUF.

Etzkowitz, H. (2003). Research groups as 'quasi-firms': the invention of the entrepreneurial university. Research Policy, 32(1), 109-121.

Etzkowitz, H., \& Kemelgor, C. (1998). The Role of Research Centres in the Collectivisation of Academic Science. Minerva: A Review of Science, Learning \& Policy, 36(3), 271288 .

EUA. (2015). Trends 2015: Learning and Teaching in European Universities (pp. 133). Brussels, Belgium: European University Association.

Frodeman, R., Klein, J. T., \& Mitcham, C. (2010). The Oxford handbook of interdisciplinarity. Oxford: Oxford University Press. 
Geiger, R. L. (1990). Organized Research Units - Their Role in the Development of University Research. The Journal of Higher Education, 61(1), 1-19.

Gibbons, A., Limoges, C., Nowotny, H., Schwarzman, S., Scott, P., \& Trow, M. (1994). The new production of knowledge, The dynamics of science and research in contemporary societies. London: SAGE Publications.

Gioia, D. A., \& Thomas, J. B. (1996). Identity, issue and image interpretation: sensemaking during strategic change in academia. Administrative Science Quarterly, 41(3), 370403.

Global Research Council (2013). Statement of Principles and Actions for Shaping the Future: Supporting the Next Generation of Researchers. Retrieved July 3, 2015, from http://www.globalresearchcouncil.org/statement- principles-research-integrity

Hackett, E. J. (2000). Interdisciplinary research initiatives at the US National Science Foundation. In P. Weingart \& N. Stehr (Eds.), Practising interdisciplinarity (pp. 248259). Toronto: The University of Toronto Press.

Holley, K. A. (2009). Interdisciplinary strategies as transformative change in higher education. Innovative Higher Education, 34(5), 331-344.

Hollingsworth, R., \& Hollingsworth, E. J. (2000). Major discoveries and biomedical research organizations: perspectives on interdisciplinarity, nurturing leadership, and integrated structure and cultures. In P. Weingart \& N. Stehr (Eds.), Practising interdisciplinarity (pp. 215-244). Toronto: University of Toronto Press

Jacobs, J. A. (2014). In defense of disciplines: Interdisciplinarity and specialization in the research university: University of chicago Press.

Jacobs, J. A., \& Frickel, S. (2009). Interdisciplinarity: A critical assessment. Annual Review of Sociology, 35, 43-65.

Jarzabkowski, P. (2008). Shaping strategy as a structuration process. Academy of Management Journal, 51(4), 621-650.

Jong, S. (2008). Academic organizations and new industrial fields: Berkeley and Stanford after the rise of biotechnology. Research Policy, 37(8), 1267-1282.

Lamont, M., Mallard, G., \& Guetzkow, J. (2006). Beyond blind faith: overcoming the obstacles to interdisciplinary evaluation. Research Evaluation 15(1), 43-55.

Lenoir, T. (1997). Instituting Science: the Cultural Production of Scientific Disciplines. California: Stanford University Press

Louvel, S. (2010). Changing authority relations within French academic research units since the 1960s: from patronage to partnership. In R. Whitley, J. Gläser \& L. Engwall (Eds.), Reconfiguring Knowledge Production: Changing Authority Relations in the Sciences and Their Consequences for Intellectual Innovation (pp. 184-210). Oxford: Oxford University Press.

Louvel, S. (2013). Understanding change in higher education as bricolage: how academics engage in curriculum change. Higher Education, 66(6), 669-691.

Louvel, S. (2015). Ce que l'interdisciplinarité fait aux disciplines: une enquête sur la nanomédecine en France et en Californie. Revue Française de Sociologie, 56(1), 6997.

MESR. (2013). France Europe 2020: un agenda stratégique pour la recherche, le transfert et l'innovation (pp. 96). Paris Ministère de l'Enseignement Supérieur et de la Recherche.

Mignot-Gérard, S. (2009). Le gouvernement d'une université face aux « Initiatives d'Excellence ». Réactivité et micro-résistances. Politiques et management public, 29(3), 519-539.

Musselin, C. (2004). The long march of French Universities. New York: Routledge.

Musselin, C., \& Dif-Pradalier, M. (2014). Quand la fusion s'impose: la (re) naissance de l'université de Strasbourg. Revue française de sociologie, 55(2), 285-318. 
Musselin, C., \& Paradeise, C. (2009). France: From incremental transitions to institutional change. In C. Paradeise, E. Reale, E. Bleiklie \& E. Ferlie (Eds.), University Governance: Western European Comparative Perspectives (pp. 21-49). Dordrecht: Springer.

Newswander, L. K., \& Borrego, M. (2009). Engagement in two interdisciplinary graduate programs. Higher Education, 58(4), 551-562.

Paradeise, C., Noël, M., \& Goastellec, G. (2015). Pression du marché, recomposition des alliances disciplinaires et impact épistémologique sur les disciplines. In A. Gorga \& J.P. Leresche (Eds.), Transformations des disciplines académiques: entre innovation et résistance. Paris: Editions des archives contemporaines

Ponomariov, B., \& Boardman, P. C. (2010). Influencing scientists' collaboration and productivity patterns through new institutions: university research centers and scientific and technical human capital. Research Policy, 39(5), 613-624.

Sá, C. M. (2008a). 'Interdisciplinary strategies' in U.S. research universities. Higher Education, 55(5), 537-552.

Sá, C. M. (2008b). Strategic Faculty Hiring in Two Public Research Universities: Pursuing interdisciplinary connections. Tertiary Education and Management, 14(4), 285-301.

Sabharwal, M., \& Hu, Q. (2013). Participation in university-based research centers: Is it helping or hurting researchers? Research Policy, 42(6), 1301-1311.

Sampat, B. N. (2012). Mission-oriented biomedical research at the NIH. Research Policy, 41(10), 1729-1741.

Stahler, G. J., \& Tash, W. R. (1994). Centers and Institutes in the Research University: Issues, Problems, and Prospects. The Journal of Higher Education, 65(5), 540-554.

Stephan, P. E. (2012). How economics shape science Cambridge, Mass.: Harvard University Press.

Thoenig, J.-C. (2015). Gouvernance organisationnelle et transformation des disciplines. In J.P. Leresche \& A. Gorga (Eds.), Transformations des disciplines académiques : entre innovation et résistance. Paris: Editions des Archives Contemporaines.

Townley, B. (1997). The institutional logic of performance appraisal. Organization Studies, 18(2), 261-285.

Vinck, D. (2000). Pratiques de l'interdisciplinarité : mutations des sciences, de l'industrie et de l'enseignement. Grenoble: PUG.

Weingart, P., \& Stehr, N. (Eds.). (2000). Practising Interdisciplinarity. Toronto: University of Toronto Press.

Whitley, R. (2003). Competition and pluralism in the public sciences: the impact of institutional frameworks on the organisation of academic science. Research Policy, 32(6), 1015-1029.

Youtie, J., Libaers, D., \& Bozeman, B. (2006). Institutionalization of university research centers: The case of the National Cooperative Program in Infertility Research. Technovation, 26(9), 1055-1063.

Zerhouni, E. (2003). The NIH roadmap. Science(302), 63-72. 


\section{Appendix}

Table 1: Synthesis of the results

\begin{tabular}{|c|c|c|c|c|c|}
\hline $\begin{array}{l}\text { Organizational } \\
\text { change settings }\end{array}$ & Main promoters & Main objectives & $\begin{array}{l}\text { Main tools for implementing } \\
\text { interdisciplinarity }\end{array}$ & $\begin{array}{l}\text { Organizational } \\
\text { change involved }\end{array}$ & $\begin{array}{l}\text { Organizational issues } \\
\text { (governance, leadership, } \\
\text { resource allocation) }\end{array}$ \\
\hline Research teams & $\begin{array}{l}\text { - Principal } \\
\text { investigators of } \\
\text { research teams }\end{array}$ & $\begin{array}{l}\text { - "creating the } \\
\text { future" (Brint, } \\
\text { 2005): innovation } \\
\text { and breakthrough } \\
\text { research for } \\
\text { economic and } \\
\text { societal needs }\end{array}$ & $\begin{array}{l}\text { - Investigator-led grants provided } \\
\text { by funding agencies } \\
\text { - university leaders do not control } \\
\text { these 'centrifugal dynamics' } \\
\text { - but they may facilitate the } \\
\text { formation of ID research teams }\end{array}$ & $\begin{array}{l}\text { - Research team } \\
\text { formation and } \\
\text { dissolution }\end{array}$ & $\begin{array}{l}\text { - Resource allocation conflict at } \\
\text { funding agencies between } \\
\text { disciplinary and interdisciplinary } \\
\text { projects } \\
\text { - No major changes in resource } \\
\text { allocation between departments }\end{array}$ \\
\hline Departments & $\begin{array}{l}\text { - 'entrepreneurial } \\
\text { academics' (among } \\
\text { faculty and } \\
\text { department deans) } \\
\text { and university } \\
\text { leaders }\end{array}$ & $\begin{array}{l}\text { - "creating the } \\
\text { future" (Brint, } \\
\text { 2005) } \\
\text { - Market } \\
\text { positioning }\end{array}$ & $\begin{array}{l}\text { - US universities: joint fund- } \\
\text { raising efforts from universities } \\
\text { and 'entrepreneurial academics' } \\
\text { - French universities: changes } \\
\text { facilitated by a ministerial policy } \\
\text { favoring their 'institutional } \\
\text { empowerment' }\end{array}$ & $\begin{array}{l}\text { - Redrawing of } \\
\text { departmental } \\
\text { boundaries: } \\
\text { - Interdisciplinary } \\
\text { departments } \\
\text { - Inter-departmental } \\
\text { structures, resources } \\
\text { and positions }\end{array}$ & $\begin{array}{l}\text { - Shift of decision-making powers } \\
\text { from department deans to } \\
\text { university leaders and } \\
\text { 'entrepreneurial academics' } \\
\text { - Resource allocation between } \\
\text { departments }\end{array}$ \\
\hline $\begin{array}{l}\text { Institutional } \\
\text { structures }\end{array}$ & $\begin{array}{l}\text { - 'entrepreneurial } \\
\text { academics' (among } \\
\text { faculty and } \\
\text { department deans) } \\
\text { and university } \\
\text { leaders }\end{array}$ & $\begin{array}{l}\text { "creating the } \\
\text { future" Brint } \\
(2005) \\
\text { - Market } \\
\text { positioning } \\
\text { - French } \\
\text { universities: } \\
\text { joining world- } \\
\text { class universities } \\
\text { by merging }\end{array}$ & $\begin{array}{l}\text { - Joint fund-raising efforts from } \\
\text { universities and 'entrepreneurial } \\
\text { academics' } \\
\text { - French universities: ministerial } \\
\text { policy favoring cooperation and/or } \\
\text { merging between universities and } \\
\text { research institutions }\end{array}$ & $\begin{array}{l}\text { - Formation of large- } \\
\text { scale team research } \\
\text { centers or projects } \\
\text { - Alliances between } \\
\text { several universities } \\
\text { and research } \\
\text { institutions }\end{array}$ & $\begin{array}{l}\text { - Resource allocation between } \\
\text { research centers and departments } \\
\text { - Competition between partnering } \\
\text { universities and institutions } \\
\text { - French universities: shift of } \\
\text { decision-making powers from } \\
\text { department deans to university } \\
\text { leaders and 'entrepreneurial } \\
\text { academics' }\end{array}$ \\
\hline
\end{tabular}

